\title{
Modelling nitrous oxide emission from soils: a tool for exploring emission reduction strategies
}

\author{
C.A. Langeveld, P.A. Leffelaar and J. Goudriaan
}

Department of Theoretical Production Ecology, Wageningen Agricultural University, P.O. Box 430, 6700 AK Wageningen, The Netherlands, Phone: +31-8370-82140/82141; Fax: +31-8370-84892, E-mail: TPELANGEVELD@RCL.WAU.NL

\begin{abstract}
Possibilities to reduce nitrous oxide $\left(\mathrm{N}_{2} \mathrm{O}\right)$ emission from soils can be explored with simulation models. In this study, principal assumptions and hypotheses underlying such a simulation model under development are presented. It uses soil water content profiles as main input data and describes production, consumption and transport of $\mathrm{N}_{2} \mathrm{O}$.

Observations on sandy grassland plots in the Wageningen Rhizolab will be used in the model development. The model is to explain the shape of the nitrous oxide profiles and the relation between subsurface nitrous oxide gradients and the observed fluxes.
\end{abstract}

\section{INTRODUCTION}

Soils are estimated to be responsible for more than $50 \%$ of the global emission of $\mathrm{N}_{2} \mathrm{O}$ [1]. Soil emission data show a large variation. This variation results from the influence of various factors on the fundamental processes denitrification, nitrification and transport that determine $\mathrm{N}_{2} \mathrm{O}$ emission from soils. These factors are temperature, aeration (related to moisture content), nitrogen mineralisation rate, amount and kind of added $\mathrm{N}$ fertiliser and content of readily decomposable carbohydrates. The current research is focussed on quantifying and modelling the influence of these factors on $\mathrm{N}_{2} \mathrm{O}$ emission from grassland soils. Some of the abovementioned factors, like aeration and fertilisation, can be manipulated in soils. These possibilities can be explored in experiments. Simulation models can be a powerful tool to guide this experimental work and to minimise the amount of work needed for giving well-based proposals for strategies to reduce $\mathrm{N}_{2} \mathrm{O}$ emissions from soils. In this paper the planned development, calibration and validation of a simulation model to describe nitrous oxide dynamics in and emission from relatively homogeneous grassland soils are outlined. In these modelling steps results of experiments in the Wageningen Rhizolab will be used $[2,3]$.

\section{MODEL CONCEPTS}

\subsection{Nitrous oxide production and consumption in the soil}

Nitrous oxide production and consumption in soils is attributed to the nitrogen transformation processes denitrification and nitrification (Figure 1). Before the modelling, a 
quantitative inventory will be made of the relative importance of these processes for nitrous oxide production and consumption under various circumstances.

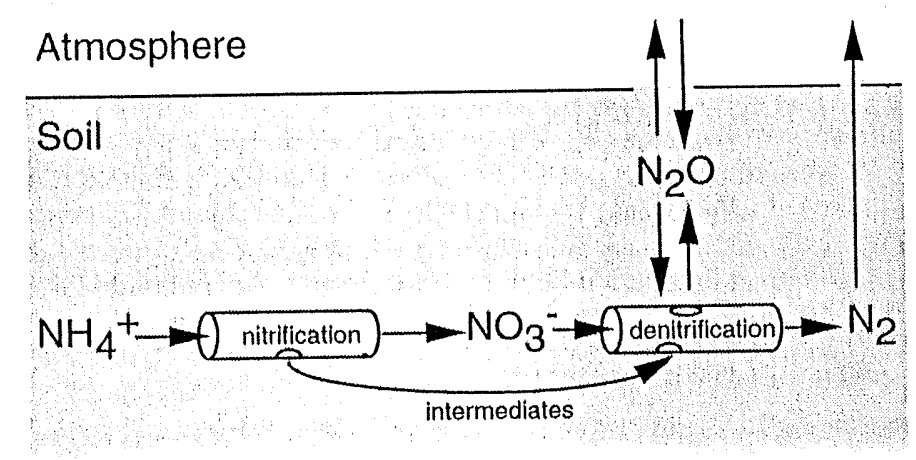

Figure 1. Hole-in-the-pipe model for nitrous oxide dynamics in and transport into or out of soils (Adapted from [4]).

\subsubsection{Denitrification}

Denitrification may occur at low partial oxygen pressures. Three types can be distinguished: biological denitrification by either heterotrophic microorganisms or autotrophic microorganisms and chemodenitrification. In all cases nitrate or nitrite is reduced. Heterotrophic biological denitrification is the most important for $\mathrm{N}_{2} \mathrm{O}$ emission from soils [5], and will be the only type taken into account in our model. The overall reaction equation is:

$5\left(\mathrm{CH}_{2} \mathrm{O}\right)+4 \mathrm{NO}_{3}{ }^{-}+4 \mathrm{H}^{+} \longrightarrow 5 \mathrm{CO}_{2}+7 \mathrm{H}_{2} \mathrm{O}+2 \mathrm{~N}_{2}+$ energy.

The reduction of nitrate $\left(\mathrm{NO}_{3}{ }^{-}\right)$in heterotrophic denitrification occurs stepwise; $\mathrm{N}_{2} \mathrm{O}$ is one of the intermediate compounds that can be either further reduced to $\mathrm{N}_{2}$ or transported to the soil surface and eventually the atmosphere:

$\mathrm{NO}_{3}{ }^{-} \rightarrow \mathrm{NO}_{2}{ }^{-} \rightarrow \mathrm{NO} \rightarrow \mathrm{N}_{2} \mathrm{O} \rightarrow \mathrm{N}_{2}$

The extent to which $\mathrm{N}_{2} \mathrm{O}$ is further reduced principally depends on the aeration of the soil, the amount of nitrate present and the residence time of $\mathrm{N}_{2} \mathrm{O}$ in a reduced soil portion. The process-based denitrification model accounting for these phenomena of [6] will be used as a starting point for model development. It essentially describes the dynamics of several (nitrogen) compounds as a result of the biological processes performed by two groups of heterotrophic bacteria: one group of strict aerobes, using only oxygen as electron acceptor, and one group of denitrifying bacteria that use either oxygen or, under anaerobic conditions, nitrate, nitrite and nitrous oxide as electron acceptors. Mineralisation and immobilisation are described in a very simplified manner.

\subsubsection{Nitrification}

Nitrous oxide production in relatively dry soils, i.e. at moisture contents below field capacity, is generally attributed to nitrification [7]. The overall reaction of nitrification is given as: 
$\mathrm{NH}_{4}+2 \mathrm{O}_{2} \rightarrow \mathrm{NO}_{3}^{-}+2 \mathrm{H}^{+}+\mathrm{H}_{2} \mathrm{O}+$ energy.

In our opinion, however, $\mathrm{N}_{2} \mathrm{O}$ production attributed to nitrification should also be classified as $\mathrm{N}_{2} \mathrm{O}$ production in denitrification, since it is essentially due to denitrification of intermediate products in nitrification.

Nitrification is performed by autotrophs as well as by heterotrophs, of which autotrophs are the most important. In fact, nitrification takes place in two steps. First ammonium $\left(\mathrm{NH}_{4}^{+}\right)$is oxidized to nitrite $\left(\mathrm{NO}_{2}{ }^{-}\right)$(ammonium oxidation). Next nitrite is oxidised to nitrate (nitrite oxidation). Nitrous oxide production from nitrification is ascribed to two processes [5]:

1. nitrifier denitrification: ammonium oxidisers use $\mathrm{NO}_{2}^{-}$as an alternative electron acceptor when $\mathrm{O}_{2}$ is (locally, temporarily) limiting and produce $\mathrm{N}_{2} \mathrm{O}$ (in fact this process is pure denitrification which occurs in nitrifying organisms),

2. a type of chemodenitrification: chemical decomposition of intermediates between $\mathrm{NH}_{4}{ }^{+}$and $\mathrm{NO}_{2}^{-}$, or $\mathrm{NO}_{2}-$ itself, to $\mathrm{N}_{2} \mathrm{O}$.

We are not aware of any existing process-based model of nitrifier denitrification. However, this process could be described analogously to the description of denitrification by [6]. The second processs cañ probably be described by elementary chemical reaction kinetics as soon as the reactions involved are identified.

\subsection{Transport of nitrous oxide within the soil and at the soil-atmosphere} interface

Several mechanisms of gas transport in soils have been distinguished [8]. Ordinary diffusion is the most important in the continuous gas phase of an unsaturated soil [9]. We assume that our system can be described as a one-dimensional system, basically governed by the reaction diffusion equation (Fick's Second Law plus production/consumption):

$\frac{\partial c}{\partial t}=\frac{\partial}{\partial z}\left\{D_{e f f} \frac{\partial c}{\partial z}\right\}+S$

where: $\quad c=$ nitrous oxide concentration,

$\mathrm{t}=$ time,

$\mathrm{z}=\operatorname{depth}(\mathrm{z}$ increasing with depth, $\mathrm{z}=0$ at the surface)

$D_{\text {eff }}=$ (modelled $)$ effective diffusion coefficient,

$\mathrm{S}=$ volumetric nitrous oxide production or consumption strength.

A more refined description of gas transport in the soil can be found in [10]. The equation describing nitrous transport at the soil-atmosphere interface is a special case of equation 1 .

\section{CALIBRATION AND VALIDATION PROCEDURE}

The model that will be developed has to be calibrated and validated. For this purpose, a twoyear experiment is performed in the Wageningen Rhizolab [2]. Regularly, nitrous oxide fluxes and belowground profiles of the soil moisture content and several gases and nutrients were determined on 4 grassland plots on a sandy soil. A portion of the results will be used for calibration. Results for the other dates will be used for validation. For validation, probably also results from other experiments, like the experiments of the Nutrient Management Institute (NMI; Velthof et al., this volume), will be used. 


\section{POTENTIAL REDUCTION STRATEGIES}

Experiments suggest that nitrous oxide emission from grassland soils could be reduced by applying suitable management practices like split application of nitrate fertilisers during dry periods $[11,12]$. The simulation model could be very helpful to explore the possibilities to reduce emissions by measures like this.

\section{ACKNOWLEDGEMENTS}

We gratefully acknowledge the support of J E Hofman, $M$ H van den Bergh, A M van Dam, the staff of the Wageningen Rhizolab, the Nutrient Management Institute (NMI) and the members of discussion group 4 of the C.T. de Wit Graduate School Production Ecology during the research and preparation of this paper. It is part of the integrated $\mathrm{N}_{2} \mathrm{O}$ grassland research project in which also participate the NMI, and the Research Institute for Agrobiology and Soil Fertility (AB-DLO), Wageningen and Haren, The Netherlands. This Project is financially supported by the Dutch National Research Program on Global Air Pollution and Climate Change (Project 852074).

\section{REFERENCES}

1 A. F. Bouwman, In A. F. Bouwman (ed.), Soils and the Greenhouse Effect, John Wiley, Chichester (1990) 61.

2 C.A. Langeveld, P.A. Leffelaar and J.Goudriaan, Submitted to the Proceedings of the $8^{\text {th }}$ Nitrogen Workshop, Ghent, Belgium, 5-8 September 1994.

3 S.C. Van de Geijn, J. Vos, J. Groenwold, J. Goudriaan and P.A. Leffelaar, Plant and Soil, 161 (1994) 275.

4 E.A. Davidson, In J.E. Rogers and W.B. Whitman (eds.), Microbial production and consumption of greenhouse gases: methane, nitrogen oxides, and halomethanes, American Society for Microbiology, Washington, D.C. (1991) 219

5 T. Granli and O.C. Bøckman, Norwegian J. Agric. Sci., 12(Supplement) (1994), 1.

6 P.A. Leffelaar and W. Wessel, Soil Sci., 146 (1988) 335.

7 D.W. Bergstrom, M. Tenuta and E.G. Beauchamp 1994, Biology and Fertility of Soils 18 (1994) 1 .

8 E.A. Mason and A.P. Malinauskas, Gas transport in porous media: The dusty-gas model, Elsevier, Amsterdam, 1983

9 D.B. Jaynes and A.S. Rogowski, Soil Sci. Soc. Am. J. 47 (1983) 425.

10 P.A. Leffelaar, Soil Sci. 143(1987)79-91.

11 O. Van Cleemput, A. Vermoesen, C.J. De Groot and K. Van Ryckeghem, In J. Van Ham, L.J.H.M. Janssen and R.J.Swart (eds.), Non- $\mathrm{CO}_{2}$ greenhouse gases. Why and how to control?, Kluwer Academic Publishers, Dordrecht (1994) 145.

12 C.J. De Groot, A. Vermoesen and O. Van Cleemput, In J. Van Ham, L.J.H.M. Janssen and R.J.Swart (eds.), Non- $\mathrm{CO}_{2}$ greenhouse gases. Why and how to control?, Kluwer Academic Publishers, Dordrecht (1994), 183. 